\begin{tabular}{c} 
OSOBA I WOlA \\
Filozofia Chrzé́cijańska $\bullet$ Tom 10, Poznań 2013 \\
Uniwersytet im. Adama Mickiewicza w Poznaniu $\bullet$ Wydziat Teologiczny \\
\hline
\end{tabular}

\author{
DAWID ROGACZ \\ Uniwersytet im. Adama Mickiewicza w Poznaniu \\ Instytut Filozofii
}

\title{
Osoba i wolność w myśli Pierre'a Teilharda de Chardina
}

The Person and the Freedom in the Thought of Pierre Teilhard de Chardin

Teilhardowska koncepcja wolności stanowi niezbadany jak dotąd wątek myśli jezuity ${ }^{1}$. Do oczywistych przyczyn tego stanu rzeczy należy zaliczyć to, że Teilhard de Chardin nie podejmuje explicite problematyki wolności, a słowa $l i$ berté próżno szukać w tytułach jego dzieł i szkiców. Eksplikacja tej części filozofii de Chardina jest wszakże konieczna dla pełnego zrozumienia personalizmu Francuza. $Z$ typowym dla siebie rozmachem Teilhard nie ogranicza się do fenomenologicznego opisu wolności osoby ludzkiej, lecz podejmuje pytanie o jej ontologiczne ugruntowanie, społeczne konsekwencje i niezbędne odniesienie religijne.

\section{WYMIAR ONTOLOGICZNY}

Aby mówić o wolności, trzeba wpierw wykazać jej możliwość, tj. ugruntować ją ontologicznie poprzez wykluczenie możliwości jednoznacznego determinizmu. W przypadku Teilharda już samo rozumienie materii odbiega od czysto jakościowego traktowania jej jako „gruboziarnistego”, stawiającego opór materiału czy od czysto ilościowej wizji materii oświeceniowych mechanicystów. Zdaniem francuskiego jezuity, takie terminy jak ,nieożywiona materia”, a nawet „materia nieświadoma”, są pewnego rodzaju nieporozumieniem. „Pomiędzy du-

\footnotetext{
${ }^{1} \mathrm{~W}$ najnowszym polskim wykazie prac o Teilhardzie de Chardin (T. Gadacz, Historia filozofii XX wieku. Nurty, t. 1, bibliografia CD, s. 87-92) oraz w archiwum Teilhard Studies [teilhardde chardin.org/ index.php/teilhard-studies - dostęp: 28.06.2013] brak artykułów i monografii dotyczących tego wątku.
} 
chem a materią nie ma takiego przeciwieństwa, jak między dwiema różnymi rzeczami czy dwiema odmiennymi naturami, lecz takie, jak między dwoma kierunkami ewolucji we wszechświecie"2. Duch i materia to dwa kierunki rozwoju tej samej rzeczywistości, dopiero izolowane w postaci oderwanych pojęć pozostaja w sprzeczności. W Fenomenie ducha (1937) mówi się dodatkowo, że są to kierunki ,poza siebie” i „wewnątrz”: pierwszy określa materię, którą znamionuje wzrastająca entropia; drugi określa ducha, którego cechuje prawo ześrodkowywania się $e^{3}$ Zasadniczo możemy przypisać Teilhardowi de Chardin cztery, rozpoznane $\mathrm{w}$ tradycji, stanowiska ontologiczne:

1) Monizm ne utralny. Przedstawiciele tego stanowiska głoszą, że substancja świata nie jest ani duchowa, ani materialna, lecz - jak mówi sama nazwa - jedna i neutralna względem tej opozycji. Oprócz Teilharda na początku XX wieku stanowisko to wyznawali Bertrand Russell i William James.

2) Parale li z m. Zwolennicy tego stanowiska głoszą, że jedna substancja ma różne (zwykle dwa) przejawy. U Benta Spinozy przejawy te nazwane są atrybutami, u Teilharda - kierunkami.

3) Hilozoi zm. Reprezentanci tego stanowiska uważają, że cała materia jest ożywiona. Pod koncepcją jońskich filozofów przyrody Teilhard podpisuje się oburącz.

4) P a n p s y hi z m. Panpsychiści twierdzą że cała materia jest świadoma. Myśl Teilharda w oryginalny sposób reinterpretuje ten pogląd, wywodzący się już od stoików.

Można zatem powiedzieć, że już najmniejsza cząstka Wszechświata była ożywiona i świadoma, choć w stopniu nieporównywalnie mniejszym od zwierząt i ludzi.

W swoim głównym dziele, Le phénomène humain, Pierre Teilhard de Chardin, pisząc o duchowym aspekcie tworzywa świata, posługuje się dwiema nośnymi filozoficznymi metaforami: koncepcją energii duchowej i pojęciem wnętrza rzeczy. Teilhard zauważa, że chociaż nauce obcy jest termin „energii duchowej”, w naszym codziennym doświadczeniu naprowadza na niego odczucie psychicznego wysiłku ${ }^{4}$. Pozwala mu to mówić zarówno o energii duchowej, jak i fizycznej, które towarzyszą sobie, przechodzą w siebie i sobie odpowiadają. W obrębie samej energii duchowej rozróżnia on ponadto energię tangencjalną i energię radialną. Energia tangencjalna wiąże ze sobą wszystkie elementy Wszechświata

\footnotetext{
${ }^{2}$ P. Teilhard de Chardin, Mój wszechświat, w: tenże, Człowiek i inne pisma, tłum. J. i G. Fedorowscy, W. Sukiennicka, M. Tazbir, Warszawa 1984, s. 122.

${ }^{3}$ P. Teilhard de Chardin, Fenomen ducha, w: tenże, Człowiek $i$ inne pisma, dz. cyt., s. 159.

${ }^{4}$ Tenże, Fenomen człowieka, tłum. K. Waloszczyk, Warszawa 1993, s. 39-40.
} 
o tym samym stopniu złożoności. Energia radialna jest przyczyną rozwoju tych elementów, tzn. „pociagga je” w stronę stanu o większej złożoności, a co za tym idzie - stanu o silniejszym ześrodkowaniu i większym psychizmie ${ }^{5}$. Dynamiczne oddziaływanie obu energii sprawia, że w świecie jako całości, po pierwsze, przybywa energii duchowej, a po drugie (w zgodzie z określeniem ducha jako kierunku jednoczenia się tworzywa świata) - następuje dążenie do coraz ściślejszego „ześrodkowania się”, tj. w ostateczności - zjednoczenia z duchowym Centrum, Bogiem.

Drugą ze wskazanych metafor filozoficznych, charakteryzujących relację ducha do materii, jest pojęcie „wnętrza rzeczy”. Termin ten ma, moim zdaniem, rodowód heglowski: „Prawdziwa istota rzeczy określiła się teraz w ten sposób, że nie jest dla świadomości czymś bezpośrednim; że świadomość pozostaje w pośrednim stosunku do wewnętrznej strony [...] wewnętrzna strona rzeczy została określona jako coś, co leży po tamtej stronie świadomości (als das Jenseits des Bewustsseins)" ". Przez „wnętrze rzeczy" Teilhard de Chardin rozumie życie psychiczne, którym odznaczają się nie tylko organizmy o wysokiej złożoności, ale wszystkie byty w ogóle ${ }^{7}$. Życie to ma charakter wewnętrzny (intymny), gdyż nie jest dostępne nikomu i niczemu poza danym bytem. Teza tej postaci ma, rzecz jasna, charakter metafizyczny, ale w pewnym sensie nie jest ona bardziej metafizyczna niż przypisywanie życia psychicznego innym ludziom. Jeśli przypisujemy wewnętrzne życie psychiczne innym organizmom poprzez analogię ich zachowania do zachowania nas samych, to ciagle na podstawie pewnych empirycznych o z nak wypowiadamy się o tym, co jest dla nas bezpośrednio nieznane. Teilhard sprowadza problem analogii do ekstremum, pokazując, że oznaką ,psychizmu" może być wyrażanie bólu czy nawet po prostu ruch.

Podsumowując tę część rozważań, można powiedzieć, że w metafizyce Teilharda nie tylko jest miejsce dla wolności, ale jest dla niej miejsce zasadnicze. Jeśli ducha rozumieć jako kierunek jednoczenia się świata, pociagający go w stronę stanów o coraz większej złożoności świadomości, a ostatecznie ku Bogu, to z pewnością ,znamieniem ducha jest wolność”. Odpowiednikiem wolności rozumianej jako zdolność inicjowania aktów jest szczególnie koncept energii radialnej - immanentnej przyczyny rozwoju bytów (swoistej entelechii). Intymne i nieprzekazywalne doświadczenie wolności znajduje swój wyraz w metaforze „wnętrza rzeczy”. Szczególnie znaczące jest, że na trop pojęcia energii duchowej naprowadziło Teilharda doświadczenie własnego wysiłku związanego z podjęciem działania. Specyficzny dla metafizyki jezuity jest fakt, że nie odmawia on wolności żadnym bytom, uznając jedynie różnice stopnia, a wyjątkowość czło-

\footnotetext{
${ }^{5}$ Tamże, s. 41.

${ }^{6}$ G.W.F. Hegel, Fenomenologia ducha, t. 1, thum. A. Landman, Warszawa 2010, s. 72, 74.

${ }^{7}$ P. Teilhard de Chardin, Fenomen człowieka, dz. cyt., s. 33.
} 
wieka widzi raczej w uświadamianiu sobie tej wolności niż w jej wyłącznym posiadaniu. W tym kontekście koncentracja Teilharda na opisie wolności osoby ludzkiej nie jest arbitralnym zabiegiem, ale próbą rozumienia tajemnicy ludzkiej wolności i wynikającej z niej odpowiedzialności.

\section{WYMIAR PERSONALISTYCZNY}

Fenomen człowieka znajduje się w centrum myśli Teilharda de Chardina, o czym świadczy chociażby częstość, z jaką słowo homme występuje w tytułach prac filozofa. W wielu kontekstach „człowiek” jest nawet synonimem wyrazu „duch”. Dzieje się tak, gdyż nasz (ludzki) dostęp do różnych postaci ducha jest zapośredniczony przez to, jak postrzegamy własną duchowość. Teilhard podkreśla, że bliskość „zjawiska człowieka” może nawet paradoksalnie przesłonić jego wyjątkowość: „Jesteśmy ludźmi, żyjemy między ludźmi i właśnie dlatego nie zdajemy sobie sprawy z ogromu i doniosłości zjawiska zwanego człowiekiem"». Przeciwnicy antropocentryzmu zwykle nie rozważają racji przemawiających za tym stanowiskiem, lecz uznają go za formę egocentrycznego odnoszenia wszystkiego do siebie lub naturalną skłonność do myślenia o sobie. Antropocentryzm Teilharda różni się jednak od klasycznych wersji tego poglądu: Norbert Wildiers określa go mianem neohumanizmu9, zaś Andrzej Zachariasz - antropotelizmu ${ }^{10}$.

Duch ludzki jest więc subiektywnie najbliższą i obiektywnie centralną perspektywą oglądu ewolucji ducha w świecie. Teilhard de Chardin wymienia trzy wymiary świadomości refleksyjnej: (a) refleksję, tj. samoświadomość; (b) korefleksję, tj. współświadomość; (c) ultrarefleksję (lub superrefleksję), tj. nadświadomośćc ${ }^{11}$. Mieczysław Tazbir odwołuje się do etymologii słowa „refleksja”, wskazując, że w przypadku superrefleksji mówimy o „odbiciu” Boga w pojedynczej jaźni ${ }^{12}$. Ujmując rzecz od strony egzystencjalnej: w przypadku (a) człowiek centralizuje się na sobie, w przypadku (b) decentralizuje się ku innym, w przypadku (c) ponownie centralizuje się, tym razem jednak na Centrum wyższym niż on sam. Model ten ma jawnie heglowski charakter: w myśl schematu teza-antyteza-synteza autotranscendencja podmiotu ku temu, co inne, kończy się wzbogaconym (na skutek Aufhebung) powrotem do siebie. Równocześnie można zauważyć, że poszczególne wymiary symbolizują kolejne stadia ewolucji ducha: (a) przej-

\footnotetext{
${ }^{8}$ P. Teilhard de Chardin, Człowiek, w: tenże, Człowiek i inne pisma, dz. cyt., s. 63.

${ }^{9}$ N. Wildiers, Ku chrześcijańskiemu neohumanizmowi, Warszawa 1964.

${ }^{10}$ A. Zachariasz, Antropotelizm: człowiek a sens istnienia, Lublin 1996.

${ }^{11}$ P. Teilhard de Chardin, Szczególne cechy gatunku Homo sapiens, w: tenże, Zarys wszechświata personalistycznego i inne pisma, thum. M. Tazbir, K. Waloszczyk, Warszawa 1985, s. 262.

${ }^{12}$ P. Teilhard de Chardin, Refleksja a energia, w: tenże, Moja wizja świata i inne pisma, thum. M. Tazbir, Warszawa 1987, s. 377.
} 
ście od świadomości do samoświadomości, (b) przejście od świadomości refleksyjnej do świadomości zbiorowej - noosfery; (c) przejście od noosfery do Nadświadomości - Omegi.

Filozofia Teilharda de Chardina mieści się w ramach personalizmu chrześcijańskiego. Po pierwsze, człowiek w filozofii Teilharda nie jest w żaden sposób wielkością daną, skończoną. Projektuje się na nowo, dokonując nieustannego przekraczania siebie (autranscendencji): „Tym, co kochamy ostatecznie w swojej osobie, jest wciąż «inny» wyprzedzający nas"'13. Zamiast mówić o osobie, należałoby raczej powiedzieć (za Mounierem) o „nieustannym ruchu personalizacji i autokreacji". Po drugie, osobę konstytuuje nie tylko refleksja, ale także żywione przez nią uczucia (przede wszystkim miłość), doświadczane cierpienia i wysiłki oraz wszystkie tajemnicze siły podświadomości, którym często ulega. „Zejdźmy w głąb siebie, powtarzam to raz jeszcze, a będziemy przerażeni, znajdując tam, poniżej świadomości ludzkiej, pod powierzchowną refleksją i płytkimi relacjami, nieznajomego zaledwie odróżniającego się od nieświadomości"14. Po trzecie, Teilhard de Chardin uważa, że socjalizacja jest własnością całej materii ożywionej; w przypadku świadomości refleksyjnej zakres owej socjalizacji wybiega poza ramy rodziny i obejmuje cały gatunek. Część badaczy argumentuje jednak, że osoba u Teilharda jest jedynie jednostką przekształconą ( $\mathrm{tj}$. uspołecznioną) przez zbiorowość ${ }^{15}$.

Teilhard de Chardin opowiada się za pozytywną wizją wolności, gdyż koncepcja wolności negatywnej liberalizmu zakłada apersonalistyczną antropologię człowieka przeciwstawionego światu i innym ludziom. Człowiek Teilharda żyje i działa w centrum (zwieńczeniu) świata tak, że jego zamiarów i oczekiwanych skutków jego przedsięwzięć w żaden sposób nie przesłania „zasłona determinizmu" ${ }^{\prime 6}$. Prawdopodobnym powodem zaniedbania przez Teilharda teoretycznych refleksji na temat wolności może być to, że jezuity nie interesowała czysto formalna struktura wolności, jej rodzaje itp., lecz jej konkretne wyrazy w relacjach międzyludzkich, życiu społecznym i modlitwie. Konkretną formą wolności odniesioną do ludzi jest u Teilharda miłość; formą wolności odniesioną do świata praca.

Znaczenie, jakie słowu l'amour nadaje Teilhard, wybiega jednak daleko poza standardowe użycie. Wynika to z tego, że Teilhard jest zarówno personalistą, dla którego miłość jest aktem konstytuującym samą osobę, jak i panpsychistą, który

\footnotetext{
${ }^{13}$ P. Teilhard de Chardin, L'Energie humaine, Paris 1962, s. 79.

${ }^{14}$ Tenże, Ècrits du temps de la guerre, Paris 1965, s. 17.

${ }^{15}$ Z. Żaba, Ewolucjonistyczny personalizm o. Teilharda de Chardin, w: Redakcja Miesięcznika „Życie i Myśl”, Myśl o. Teilharda de Chardin w Polsce, Warszawa 1973, s. 161.

${ }^{16}$ P. Teilhard de Chardin, Fenomen czlowieka, w: tenże, Moja wizja świata i inne pisma, dz. cyt., s. 73.
} 
przyznaje świadomość wszystkim bytom. Prowadzi to do stwierdzenia, że miłość jest „lgnięciem” jednego bytu do drugiego, zaczątkiem socjalizacji ujętym od „strony wewnętrznej” procesu ${ }^{17}$. Miłość jest energią kosmiczną, budującą Wszechświat ${ }^{18}$. Energia ta, jak duch, podlega jednak stopniowaniu. Namiętności płciowe, instynkt macierzyński i ojcowski czy solidarność grupowa to dla Teilharda modi miłości w świecie zwierzęcym. Miłość dwóch osób ma, rzecz jasna, nieporównanie większą wartość. Teilhard mówił do nowożeńców: „Skoncentrowanie się elementu na samym sobie [...] nie skusiło was [...] Wybraliście jedność przez zespolenie się. I dobrze wybraliście [...] Prawdziwe zjednoczenie różnicuje - w tej samej mierze, w jakiej zespala"19. Określenie miłości jako l'union différencié podkreśla, że miłość stanowi realizację wolności, a nie jej zaprzeczenie, dar z siebie samego, który - nawet jeśli wiąże się z ofiarą - prowadzi do duchowego rozwoju i „swobodnego ujścia” ducha ${ }^{20}$. Czystość stanowi jedną $\mathrm{z}$ form tak rozumianej miłości, nigdy jej zaprzeczenie ${ }^{21}$.

Inną konkretyzacją wolności jest praca. Każda praca jest ascezą, umieraniem poprzez czyn, wysiłkiem duchowego doskonalenia się ${ }^{22}$. Ponieważ świat nieustannie ewoluuje, ludzka praca ma wpływ na jego kształt, buduje Wszechświat. Teilhard formuluje nawet swoisty imperatyw (przechodząc z poziomu deskryptywnego na normatywny): „We wszystkim przyczyniać się do organicznego jednoczenia się świata i we wszystkim mu ulegać" ${ }^{23}$. Choć każdy wysiłek przybliża człowieka do śmierci (,umieranie poprzez czyn”), rezultaty pracy człowieka są trwałe i w pewnym sensie nieśmiertelne. Teilhard formułuje powyższy imperatyw, aby pokrzepić tych, którzy w tę prawdę zwątpili. De Chardin uważa, że tak rozumiana wiara $\mathrm{w}$ przyszłość stanowi niezbędną motywację wszelkiej pracy, warunek możliwości podjęcia jakiegokolwiek wysiłku. Człowiek musi mieć pewność, że jego wysiłki nie idą na marne i że pomogą mu w samorealizacji, inaczej nie podjąłby się działania ${ }^{24}$. W wysiłku tym znacząco wspomaga człowieka chrześcijaństwo, które w przeciwieństwie do religii Dalekiego Wschodu nie po-

${ }^{17}$ P. Teilhard de Chardin, O szczęściu, cierpieniu i miłości, tłum. W. Sukiennicka, M. Tazbir, Warszawa 2001, s. 257.

${ }^{18}$ P. Teilhard de Chardin, Człowiek..., dz. cyt., s. 120-121.

${ }^{19}$ Tenże, Przemówienie wygloszone podczas uroczystości zaślubin państwa de la Goublaye de Ménerval w kościele Świętego Ludwika (Inwalidów) 15 czerwca 1935r., w: tenże, Zarys wszechświata..., dz. cyt., s. 226.

${ }^{20}$ Tenże, Przemówienie wygłoszone 14 czerwca 1928r. w kościele Świętego Augustyna w Paryżu podczas zaślubin Odety Bacot z Janem Teilhardem d'Eyry, w: tenże, Moja wizja świata ..., dz. cyt., s. 224.

${ }^{21}$ Tenże, Ewolucja pojęcia czystości, w: tenże, Zarys wszechświata..., dz. cyt., s. 89.

${ }^{22}$ Tenże, Mój Wszechświat, dz. cyt., s. 138-139.

${ }^{23}$ Tamże, s. 135.

${ }^{24}$ P. Teilhard de Chardin, Problem działania, w: tenże, Człowiek..., dz. cyt., s. 199. 
tępia doczesności i cielesności, czego najlepszym wyrazem są prawdy wiary: wcielenia i zmartwychwstania ${ }^{25}$.

Jedną z nieuniknionych konsekwencji wolności pozytywnej jest cierpienie. Teilhard de Chardin traktuje je jako „efekt uboczny” wysiłku miłości i pracy. Cierpienie ma tym samym wartość konstruktywną: „Ludzkie cierpienia, suma cierpień doznawanych w każdej chwili na całym świecie - to przeogromny ocean. Z czego się jednak składa ta masa? Z czerni? Z braków? [...] Nie, powtarzam raz jeszcze, składa się ona $z$ energii potencjalnej. W cierpieniu kryje się w ogromnym stężeniu - skierowana w górę siła świata"26. Z wolnością nie można jednak mylić Teilhardowskiego konceptu woli życia, oznaczającego dyspozycję psychiczna, zarazem intelektualną i afektywną, dzięki której świat jako całość jawi się jako pociagający ${ }^{27}$. „Wola (resp. chęć) życia” jest pojęciem osadzonym w klimacie intelektualnym modernizmu: ,woli życia” (Schopenhauer), „woli mocy” (Nietzsche) czy „woli wiary” (James). Fenomen cierpienia prowadzi natomiast do zagadnienia konsekwencji wolności ludzkiej, a przede wszystkim - jej skutków społecznych.

\section{WYMIAR SPOŁECZNY}

Żyjemy w świecie wolnych osób i wolność każdego z nas nie może być samowolą. Kwestia społecznych konsekwencji wolności i odpowiedzialności za podjęte działanie dotyczy szczególnie wolności pozytywnej, która - w przeciwieństwie do „wolności nowożytnych" - nie ogranicza się do wytyczenia nienaruszalnej sfery prywatnych uprawnień. Teilhard de Chardin zdawał sobie z tego sprawę, wierząc głęboko, że społeczeństwo stanowi raczej przestrzeń realizacji wolności, realizacji o zasięgu nieosiagalnym przez pojedyncze osoby, niż przeszkodę w pełnym rozwinięciu własnych możliwości. Wierzył też we wspólne ukierunkowanie wysiłków ludzkich (zbieżność dążeń), czego najlepszym wyrazem była jego koncepcja noosfery.

Socjalizacja, rozumiana jako proces tworzenia związków międzyludzkich, ma swój naturalny rezultat w postaci totalizacji: psychicznego zjednoczenia, scalenia $\operatorname{się}^{28}$. Oczywiście, można by się zastanowić, czy socjalizacja musi prowadzić do totalizacji (zjednoczenia całej ludzkości), tzn. czy nie ogranicza się do grup społecznych bądź narodów, zatrzymując się na tym etapie. Teilhard bierze

${ }^{25}$ P. Teilhard de Chardin, Sedno zagadnienia, w: tenże, Człowiek..., dz. cyt., s. 259, 262.

${ }^{26}$ Tenże, Znaczenie i konstruktywna wartość cierpienia, w: tenże, Mój wszechświat..., dz. cyt., s. 12.

${ }^{27}$ Por. K. Waloszczyk, Wola życia. Myśl Pierre’a Teilharda de Chardin, Warszawa 1986, s. 187.

${ }^{28}$ P. Teilhard de Chardin, Czlowiek..., dz. cyt., s. 83. 
to pod uwagę, argumentując, że dwie krzywizny - psychiczna (dążność do kontaktu z innymi ludźmi) i ziemska - prowadzą do tego, że prędzej czy później nastapi zjednoczenie ludzkości. Po zakończeniu etapu ekspansji, z uwagi na skończoną powierzchnię Ziemi, rozpoczyna się etap koncentracji, czyli zjednoczenia ludzkości ${ }^{29}$. Odpowiadająca koncentracji personalizacja oznacza, że zwieńczeniem totalizacji nie będzie rozproszona świadomość zbiorowa, lecz jej nadosobowa realizacja - punkt omega. Teilhard odcina się od wiązania totalizacji z totalitaryzmem. Właściwą formułą uspołecznienia ludzkości jest „zjednoczenie w zróżnicowaniu" (l’union différencié): w przeciwieństwie do indywidualizmu personalizm nie zakłada, że społeczeństwo niesie ze sobą zagładę pełni praw i możliwości jednostki, lecz odwrotnie: to społeczeństwo doskonali osobę, „wydobywając na światło dzienne" ukryte zdolności człowieka ${ }^{30}$. W duchu totalizacji personalizującej Teilhard stwierdza ponadto, że nie można kochać ludzkości jako takiej i miłość do wszystkich osób musi być ostatecznie miłością do jednej Osoby, która je spaja.

Właściwą przestrzenią realizacji wolności w skali ludzkości jest noosfera „myśląca powłoka Ziemi”. Pojęcie noosfery zostało po raz pierwszy użyte w pracy $O$ hominizacji $(1925)^{31}$. Nie dokonując tu szczegółowej charakterystyki noosfery $^{32}$, należy podkreślić, że noosfera $\mathrm{w}$ żaden sposób nie sprowadza się do kultury czy nawet czegoś w rodzaju „trzeciego świata” Karla Poppera. Chociaż wiedza naukowa i techniczna zajmuje poczesne miejsce w całokształcie noosfery, nie wyczerpuje jej uniwersum: noosferę zasila także „energia miłości”, czyniąc z niej „Wszechświat personalistyczny”. Społeczny wymiar wolności oznacza bowiem społeczny kontekst wolności i pracy. „Czymże więc jest to wszystko, jeśli nie genezą zbiorowego i jedynego aktu, w którym, przybierając postać miłości (jedynie możliwą postać), urzeczywistniałyby się, zbliżając się do swej dojrzałości, czyli do ostatecznego zjednoczenia, siły osobowości zawarte w noosferze" ?33 Nie mniej istotne są społeczne skutki realizacji osoby poprzez pracę: przekonanie, że wysiłki duchowe każdego człowieka raczej „dokładają” do dziedzictwa poprzednich pokoleń, niż budują od nowa, jest gwarantem wiary w postęp ludzkości. Wiara w postęp stanowi zaś niezbędną motywację w podejmowaniu fizycznego i duchowego wysiłku ${ }^{34}$. Specyficzną cechą myśli Teilharda jest

${ }^{29}$ Tamże, s. 89-90.

${ }^{30}$ P. Teilhard de Chardin, Zarys Wszechświata personalistycznego, dz. cyt., s. 66.

${ }^{31}$ Tenże, L'Hominisation. Introduction a une étude scientifique du phénomène humain w: tenże, Oeuvres, t. 3, Paris 1962, s. 92.

${ }^{32}$ Por. G. Pacewicz, Koncepcja noosfery w myśli Pierre'a Teilharda de Chardin, Olsztyn 2010. Por. także: Z. Łotys, Teilhardowska koncepcja postępu, Olsztyn 1998.

${ }^{33}$ P. Teilhard de Chardin, Energia miłości, w: tenże, Człowiek $i$ inne pisma, dz. cyt., s. 183.

${ }^{34}$ Tenże, Problem działania, w: tenże, Człowiek i inne pisma, dz. cyt., s. 199. 
przekonanie, że postęp ludzkości ma nie tylko charakter liniowy (kumulatywny), ale jest też nieodwracalny. Konieczność postępu ma źródło w metafizycznych zasadach systemu jezuity: jeśli proces ,ześrodkowywania się” ducha, który doprowadził do powstania noosfery, kieruje jej dalszym rozwojem, to w skali dziejów ludzkości zwieńczeniem tego postępu będzie punkt doskonałej ,jedności w zróżnicowaniu", punkt Omega. Rodzi to pytanie o religijny wymiar wolności osoby ludzkiej.

\section{WYMIAR RELIGIJNY}

Wbrew obecnemu w pracach Teilharda porządkowi prezentacji kolejnych „odsłon” ducha należy powiedzieć, że Omega jest najważniejszym bytem w metafizyce myśliciela: porządek genetyczny stanowi odwrócenie porządku logicznego. Omega nie jest bowiem czymś, co ma dopiero przyjść, lecz istnieje już aktualnie. Założenie o aktualności Omegi oznacza zatem, że Omega jest Bogiem. Ponieważ punkt Omega wieńczy totalizację ludzkości i personalizację każdego człowieka z osobna, Bóg Teilharda jest także Bogiem osobowym. Z Bogiem tym można nawiązywać relacje, z których najważniejsza jest miłość. Miłość do Boga uświęca każdy wysiłek i stanowi nieocenioną motywację do pracy nad sobą i doskonalenia świata ${ }^{35}$. Aktualność Omegi przejawiałaby się także w tym, że nie można kochać osoby, która nie istnieje. Do takiej Osoby nie można by się modlić ani Jej adorować, co jednak ma miejsce - uważa Teilhard ${ }^{36}$. Jako że kochać mogą się tylko osoby, miłość kosmiczna i miłość do ludzkości wyrażają się jedynie poprzez miłość do Tego, który ma nadejść. Nie można kochać idei, a zwłaszcza nie można miłować ludzkości w sposób, w jaki uczynił to m.in. Comte. Relacje między Bogiem i światem nie są jednakowoż jednostronne. Bóg pozostaje do świata $\mathrm{w}$ relacji, którą de Chardin nazywa ,jednoczącym działaniem stwórczym" ${ }^{37}$. Bóg osobowy jest tym samym Stwórcą. Teilhard sprzeciwia się jednak interpretacji stworzenia jako czegoś w rodzaju jednorazowego aktu, który spowodował powstanie pierwszego atomu, zwalniając Boga z obowiązku „zajmowania się" światem. Ponieważ Bóg jest poza czasoprzestrzenią, przedmiotem creatio ex nihilo jest świat jako całość. Creatio continua, czyli Opatrzność w najmocniejszym sensie tego słowa, nie jest - jak sądzili deiści - „dodatkiem” do filozoficznej idei Stwórcy, ale najgłębszym sensem stworzenia.

Stworzenie jest według Teilharda nie tylko wolnym aktem, ale jako jednoczące działanie stwórcze (na tyle, na ile rozumiemy ducha jako kierunek jednocze-

\footnotetext{
${ }^{35}$ P. Teilhard de Chardin, Fenomen ducha, w: tenże, Człowiek i inne pisma, dz. cyt., s. 171.

${ }^{36}$ Tenże, Kapłan, w: tenże, Moja wizja świata ..., dz. cyt., s. 15.

${ }^{37}$ Tenże, Mój Wszechświat, dz. cyt., s. 115.
} 
nia się świata) jest warunkiem możliwości wolności stworzeń. Wolność jest darem Boga. Operując kategoriami Arystotelesowskimi, można rzec, że Bóg jest przyczyną sprawczą wolności stworzeń, a jednocześnie - przyczyną celową tej wolności ${ }^{38}$. Więcej, jako Stwórca nieustanny, przyczyna ducha i źródło jedności świata Bóg jest obecny w swoim stworzeniu: stwarzając, Bóg jednoczy się ze stworzeniem $^{39}$. Uzupełnieniem tych pięknych słów de Chardina mogłyby być słowa ojców Vaticanum II: „Syn Boży, przez wcielenie swoje zjednoczył się jakoś z każdym człowiekiem" "40. Sam Teilhard nie ukrywa przy tym, że ma na myśli właśnie Drugą Osobę Trójcy Świętej: wcielenie Słowa miało, jego zdaniem, wymiar kosmiczny, a Ciałem Mistycznym Chrystusa jest cały kosmos ${ }^{41}$. Jezuita odwołuje się w tym zakresie do teologii św. Pawła, a zwłaszcza do sformułowania z Kol 3,11: „w Nim [tj. w Chrystusie] wszystko ma swój byt”. Zrozumiałe, że w obliczu panchrystyzmu specyficzną interpretację zyskuje także katolicki sakrament Eucharystii: Eucharystia jest przedłużeniem fizycznej obecności Chrystusa historycznego i antycypacją nadejścia Chrystusa Wszechświata, „rzeczywistym centrum osobowej energii Chrystusowej" ${ }^{\prime 2}$.

„Panchrystyzm”, bo tak nazywa Teilhard swoje stanowisko, nie jest panteizmem. Wolność Boga warunkuje, a nie wyklucza, wolność człowieka: zjednoczenie z Bogiem ma charakter personalizujący, różnicujący, uwznioślający. Filozof mówi o potrzebie nowej mistyki - mistyki zdynamizowanej i zuniwersalizowanej. Z pozycji personalistycznych krytykuje $\mathrm{w}$ wielu miejscach panteizm, czyniący $z$ osoby pojedynczą modyfikację wiecznej substancji. Teilhard odrzuca zarówno panteizm hinduskiej Wedanty, jak i panteizmy humanistyczne. Jego zdaniem, dla filozofów Dalekiego Wschodu materia jest zbędnym balastem, a jedyną drogą do mistyki jedności jest zupełne zniesienie (unieważnienie) mnogości. Panteizmy humanistyczne są zaś „religiami bez wyraźnego Boga i bez objawienia”43. Podsumowując, Teilhard pisze: „Religie Indii wywarły na mnie wrażenie przepastnej głębi, w którą człowiek rzuca się, by pochwycić odbicie słońca. Dzisiejsze panteizmy humanistyczne to dla mnie perspektywa uduszenia się pod zbyt niskim niebem"44.

Wolność w wymiarze religijnym, a właściwie - w wymiarze chrześcijańskim, jest ostateczną i pełną charakterystyką wolności. Zjednoczenie z Bogiem perso-

${ }^{38}$ A.N. Williams, The Traditionalist malgré lui: Teilhard de Chardin and Ressourcement w: G. Flynn, P. Murray, Ressourcement: A Movement for Renewal in Twentieth-Century Catholic Theology, Oxford 2011, s. 115.

${ }^{39}$ P. Teilhard de Chardin, Chrystianizm a ewolucja, w: tenże, Moja wizja świata, dz. cyt., s. 149.

${ }^{40}$ Konstytucja duszpasterska o Kościele w świecie współczesnym Gaudium et spes 22.

${ }^{41}$ P. Teilhard de Chardin, Mój Wszechświat, dz. cyt., s. 125.

${ }^{42}$ Tenże, Msza na oltarzu Ziemi, w: tenże, Moja wizja świata..., dz. cyt., s. 52, 55.

${ }^{43}$ Tenże, Jaka jest moja wiara, w: tenże, Zarys wszechświata ..., dz. cyt., s. 41-42.

${ }^{44}$ Tamże, s. 43. 
nalizuje i uwzniośla ludzką miłość i pracę, pozwalając wznieść się na „nadosobowy" poziom.

\section{PODSUMOWANIE}

Pojęcie wolności jest nieeksplikowanym horyzontem myśli Pierre'a Teilharda de Chardin. Ontologicznym ugruntowaniem możliwości wolności jest koncepcja ducha jako kierunku jednoczenia się Wszechświata i pojęcie energii radialnej. Wolne, choć w różnym stopniu, są wszystkie byty posiadające duchowe „wnętrze". Osobę ludzką wyróżnia świadomość swojej wolności. Konkretną realizacją jej wolności jest miłość i praca; z pojęciem wolności nie należy jednak mylić „woli życia”. Jednoczenie się ludzkości i postęp to społeczne konsekwencje wolności ludzi. Miłość do Boga stanowi najpełniejszą motywację do podejmowania wysiłku, a sam Bóg jest ostateczną przyczyną i celem wolności stworzenia.

\section{BIBLIOGRAFIA}

Flynn G., Murray P., Ressourcement: A Movement for Renewal in Twentieth-Century Catholic Theology, Oxford 2011.

Gadacz T., Historia filozofii XX wieku. Nurty, t. 1, Kraków 2009.

Hegel G.W.F., Fenomenologia ducha, t. 1, tłum. A. Landman, Warszawa 2010.

Łotys Z., Teilhardowska koncepcja postępu, Olsztyn 1998.

Myśl o. Teilharda de Chardin w Polsce, Warszawa 1973.

Pacewicz G., Koncepcja noosfery w myśli Pierre'a Teilharda de Chardin, Olsztyn 2010.

Teilhard de Chardin P., Człowiek i inne pisma, tłum. J. i G. Fedorowscy, W. Sukiennicka, M. Tazbir, Warszawa 1984.

Teilhard de Chardin P., Fenomen człowieka, tłum. K. Waloszczyk, Warszawa 1993.

Teilhard de Chardin P., L'Energie humaine, Paris 1962.

Teilhard de Chardin P., Zarys wszechświata personalistycznego i inne pisma, tłum. M. Tazbir, K. Waloszczyk, Warszawa 1985.

Teilhard de Chardin P., Ècrits du temps de la guerre, Paris 1965.

Teilhard de Chardin P., Moja wizja świata i inne pisma, tłum. M. Tazbir, Warszawa 1987.

Teilhard de Chardin P., O szczęściu, cierpieniu i miłości, thum. W. Sukiennicka, M. Tazbir, Warszawa 2001.

Teilhard de Chardin P., Oeuvres, t. 3, Paris 1962.

Waloszczyk K., Wola życia. Myśl Pierre'a Teilharda de Chardin, Warszawa 1986.

Wildiers N., Ku chrześcijańskiemu neohumanizmowi, Warszawa 1964. 
Zachariasz A., Antropotelizm: człowiek a sens istnienia, Lublin 1996.

Z. Żaba, Ewolucjonistyczny personalizm o. Teilharda de Chardin, w: Redakcja Miesięcznika „Życie i Myśl”, Myśl o. Teilharda de Chardin w Polsce, Warszawa 1973.

http://www.kns.gower.pl/vaticanum/gaudium.htm [dostęp: 27.01.2014].

http://www.teilharddechardin.org/index.php/teilhard-studies [dostęp: 27.01.2014].

\section{SUMMARY}

The idea of freedom in the thought of Pierre Teilhard de Chardin has not already been analysed. This paper delves into this issue in four dimensions: ontological, anthropological, social and theological. The concept of spirit as unifying direction of evolution of the universe and the notion of radial energy guarantee the ontological possibility of freedom. Human person is different from other beings because of her consciousness of his own freedom. Specific embodiments of this freedom are love and work; freedom should not be confused with "the will to live". Unification and development of the mankind are main social consequences of freedom. God is the ultimate cause and the purpose of freedom, because the love of God is the most complete incentive to make an effort.

\section{Keywords}

Teilhard de Chardin, freedom, personalism, French philosophy

\section{Słowa kluczowe}

Teilhard de Chardin, wolność, personalizm, filozofia francuska 